\title{
KINERJA PELABUHAN PERIKANAN NUSANTARA KEJAWANAN CIREBON JAWA BARAT
}

\author{
Performance of Kejawanan Nusantara Fishing Port Cirebon West Java
}

Oleh:

Agus Suherman¹, Herry Boesono², Faik Kurohman³, Abdul Kohar Mudzakir ${ }^{4}$

\begin{abstract}
${ }_{1}^{1}$ Departemen Perikanan Tangkap, Fakultas Perikanan dan Ilmu Kelautan, Universitas Diponegoro.lpgsuherman2@gmail.com ${ }^{2}$ Departemen Perikanan Tangkap, Fakultas Perikanan dan Ilmu Kelautan, Universitas Diponegoro. herryboesono@gmail.com ${ }_{3}^{3}$ Departemen Perikanan Tangkap, Fakultas Perikanan dan Ilmu Kelautan, Universitas Diponegoro. faikkurohman@undip.ac.id

${ }^{4}$ Departemen Perikanan Tangkap, Fakultas Perikanan dan Ilmu Kelautan, Universitas Diponegoro. akohmud@gmail.com
\end{abstract}

* Korespondensi: lpgsuherman2@gmail.com

Diterima: 22 Juli 2020; Disetujui: 30 November 2020

\begin{abstract}
The purpose of this study is to analyze operational activities and determinants of Kejawanan Nusantara Fishing Port (NFP) performance. This research was conducted from October 2019 to March 2020 at the Kejawanan NFP. Data analysis was performed using two methods; the first is a descriptive method which is to analyze the operational activities of Kejawanan NFP and the assessment of Kejawanan NFP Performance based on guidelines issued by General Director of Capture Fisheries Number 20/KEP-DJPT/ 2015; the second is the Structural Equation Model (SEM) method, which is to define the determinants of Kejawanan NFP performance. The results of this study indicate that the operational activities of Kejawanan NFP continue to increase. Ship visits during 2019 increased by 438 times. The production value of landed fish in 2019 was Rp $147,301,194,670$. Compared to 2018, production volume in 2019 decreased as many as $16.63 \%$ with the amount of 711.9 tonnes. On the other hand, production value from 2018 to 2019 also decreased by $R p$ 26,408,892,685. Performance assessment on 27 criterias based on guidelines issued by General Director of Capture Fisheries in 2015 showed that performance of Kejawanan NFP ranged between 70.25 and 86.5. During period of study from October 2019 to March 2020 the port showed well performances, with the best one was shown in November 2019. Based on SEM test results, internal variables have the most influence on Kejawanan NFP performance.
\end{abstract}

Keywords: : Fishing Port, Kejawanan, Performance, Structural Equation Model (SEM)

\section{ABSTRAK}

Penelitian ini bertujuan menganalisis aktivitas dan kinerja operasional serta faktor-faktor penentu kinerja Pelabuhan Perikanan Nusantara Kejawanan. Penelitian ini dilaksanakan pada Oktober 2019 hingga Maret 2020 di PPN Kejawanan. Analisis data dilakukan dengan dua metode; pertama metode deskriptif yaitu untuk menganalisis aktivitas operasional dan penilaian kinerja operasional berdasarkan Keputusan Direktur Jenderal Perikanan Tangkap tahun 2015 Nomor 20/KEP-DJPT/ 2015; kedua metode Structural Equation Model (SEM) untuk mengetahui faktor-faktor penentu kinerja PPN Kejawanan. Hasil penelitian menunjukkan bahwa aktivitas operasional PPN Kejawanan terus mengalami peningkatan. Frekuensi kunjungan kapal pada tahun 2019 adalah 434 kali. Nilai Produksi ikan yang didaratkan di PPN Kejawanan pada tahun 2019 sejumlah Rp 147.301.194.670,-. Produksi tahun 2019 bila dibandingkan dengan nilai produksi tahun 2018 mengalami penurunan sebesar $16,63 \%$ atau setara dengan 711,09 ton, sedangkan nilai produksi juga mengalami penurunan dibanding tahun 2018 yaitu sebesar Rp 26.408.892.685,-. Penilaian kinerja terhadap 27 kriteria berdasarkan pedoman yang ditetapkan oleh Direktur Jenderal Perikanan 
Tangkap tahun 2015 bahwa kinerja operasional PPN Kejawanan adalah sebesar 70,25 - 86,50. Selama Oktober 2019 hingga Maret 2020 pelabuhan menunjukkan kinerja baik bahkan pada November 2019 kinerjanya sangat baik. Berdasarkan hasil pengujian SEM, internal variabel mempunyai pengaruh paling besar terhadap kinerja PPN.

Kata kunci: Pelabuhan Perikanan, Kejawanan, Kinerja, Structural Equation Model (SEM)

\section{PENDAHULUAN}

Pelabuhan perikanan (PP) memiliki nilai strategis untuk pengembangan usaha perikanan dan nelayan (Suherman, 2007; Gumilang dan Susilawati 2019). Prospek pembangunan PP adalah terlaksananya pemerataan pembangunan, perluasan kesempatan kerja dan berkurangnya arus urbanisasi. Hal ini akan meningkatkan taraf hidup dan kesejahteraan rakyat pada umumnya dan nelayan pada khususnya. Sebagaimana diatur dalam KEPMEN KP Nomor 6/Kepmen-KP/2018, PP merupakan tempat yang terdiri atas daratan dan perairan di sekitarnya dengan batas-batas tertentu sebagai tempat kegiatan pemerintahan dan kegiatan sistem bisnis perikanan yang digunakan sebagai tempat kapal perikanan bersandar, berlabuh, dan/atau bongkar muat ikan yang dilengkapi dengan fasilitas keselamatan pelayaran dan kegiatan penunjang perikanan. Apabila fungsi pemerintahan dan sistem bisnis perikanan tersebut berjalan dengan baik, maka PP akan berdaya guna sebagai pusat aktivitas industrialisasi kelautan perikanan yang akan memberikan dampak pada peningkatan pertumbuhan ekonomi domestik dan pengentasan kemiskinan. Pelabuhan perikanan yang berfungsi dengan baik akan merupakan titik temu (terminal point) yang menguntungkan antara kegiatan ekonomi di laut dengan kegiatan ekonomi di darat (Lubis dan Pane 2012; Lubis dan Pane 2017; Purnomo et al. 2003; Suherman 2010; Suherman dan Dault, 2009; Suherman 2011).

PPN Kejawanan terletak di Kelurahan Lemah Wungkuk, Kota Cirebon, tepatnya pada posisi 060-44'-14" LS/1080-34'-53" BT, dan telah dilengkapi dengan berbagai sarana seperti sarana pokok, sarana fungsional dan sarana tambahan/penunjang. Secara geografis lokasi PPN Kejawanan sangat strategis karena merupakan pintu gerbang Jawa Barat bagian timur dan dengan mudah menghubungkan daerah pemasaran potensial yaitu Bandung dan Jakarta sekaligus sebagai pintu gerbang keluar masuknya arus komoditi barang ekspor impor yang berfungsi sebagai pusat perdagangan dan industri serta wisatawan domestik maupun asing ke Cirebon (Widagdo 2015). PPN Kejawanan merupakan salah satu dari dua PPN Tipe B yang ada di Jawa (Ruswandi dan Gartika 2013; Sudirman et al. 2013). Mengingat perannya yang sangat strategis dalam pengembangan ekonomi wilayah, kinerja PPN Kejawanan perlu dikaji dan ditingkatkan agar dapat memberikan pelayanan terbaik.

Beberapa penelitian terkait dengan kinerja PPN Kejawanan telah dilakukan sebelumnya, antara lain dilakukan oleh Ramadhani et al. (2015) yang mengukur tingkat pemanfaatan fasilitas dan strategi pengembangan PPN Kejawanan. Penelitian lain juga dilakukan oleh Bayyinah et al. (2016) yang mengkaji mengenai kepuasan nelayan terhadap pelayanan PPN Kejawanan Cirebon, menggunakan pendekatan Importance and Performance Analysis (IPA) dan Customer Statisfaction Index (CSI) dengan 15 atribut penilaian. Selain itu, analisis tingkat kepuasan nelayan terhadap pelayanan kesyahbandaran juga telah dilakukan oleh Supriadi dan Fitri (2019). Selanjutnya, Juhaeriyah et al. (2018) telah melakukan kajian mengenai perkembangan PPN Kejawanan dan kontribusinya terhadap pemberdayaan sosial ekonomi masyarakat nelayan Kota Cirebon, 1994-2011. Sementara itu, Gumilang dan Susilawati (2019) telah meneliti terkait analisis rantai pasok dalam distribusi hasil tangkapan berbasis komoditas unggulan di PPN Kejawanan.

Berdasarkan pada penelitian yang telah ada sebelumnya, area pengukuran kinerja yang masih belum dilakukan adalah kinerja pengelolaan atau manajemen pelabuhan dalam menjalankan fungsinya. Sehingga, perlu adanya sebuah penelitian yang bertujuan untuk menganalisis aktivitas dan kinerja serta mengetahui faktor-faktor penentu kinerja PPN Kejawanan.

\section{METODE}

Penelitian ini dilaksanakan pada Oktober 2019 hingga Maret 2020 di PPN Kejawanan dengan memanfaatkan data kuantitatif dan kualitatif. Analisis data dilakukan dengan dua metode; pertama metode deskriptif untuk menganalisis kinerja PPN Kejawanan (sebagai tujuan pertama dari penelitian ini) dan kedua metode Structural Equation Model (SEM) yaitu untuk 
mengetahui faktor-faktor penentu kinerja PPN Kejawanan. Metode deskripsi dilakukan dengan membuat paparan berdasarkan data aktivitas operasional (meliputi kunjungan kapal perikanan, data produksi, nilai produksi, penyaluran logistik) PPN Kejawanan, dilanjutkan dengan menilai kinerja operasional berdasarkan Keputusan Direktur Jenderal Perikanan Tangkap tahun 2015 Nomor 20/KEP-DJPT/ 2015. Selanjutnya, SEM digunakan dalam menganalisis dan mengintrepretasikan data yang telah disesuaikan dengan model yang dikembangkan dalam penelitian menggunakan program AMOS 2.2 (Ghozali 2014). Alat analisis ini dipilih karena kemampuannya dalam menguji proses yang rumit yang dirangkai secara berhubungan (Ferdinand 2006; Deng et al. 2013; Gonçalves dan Assumpção 2016; Munim et al. 2018; Sharapiyeva et al. 2019; Roring et al. 2020). Tahapan proses analisis data menggunakan SEM sebagai berikut: mengembangkan model berdasar teori; menyusun diagram jalur; menyusun persamaan struktural; memilih jenis input matriks dan estimasi model yang diusulkan; menilai identifikasi model struktural; menilai kriteria goodness-of-fit; serta menginterpretasi dan memodifikasi model.

Populasi yang menjadi subyek penelitian ialah nelayan, pedagang ikan, pengolah ikan dan mitra kerja, serta pegawai PPN Kejawanan. Pengumpulan data primer dibantu dengan menggunakan daftar kuesioner. Jumlah sampel minimum yang dibutuhkan untuk penelitian ini dihitung berdasarkan jumlah indikator dan kriteria sampel minimum SEM. Analisis SEM membutuhkan sampel sebanyak paling sedikit 5 kali jumlah indikator. Jumlah indikator yang akan diteliti adalah 20, sehingga jumlah minimum respondennya adalah 100 orang (dari 20 dikali 5). Pada pengujian Chisquere model SEM yang sensitif terhadap jumlah sampel dibutuhkan sampel yang baik berkisar antara 100-200 sampel untuk teknik maximum likelihood estimation (Ferdinand 2014). Sampel yang digunakan dalam penelitian ini sebanyak 138 responden dan sesuai dengan prosedur estimasi Maximum Likehood Estimation Method (MLE) mengenai sampel minimum yang diajukan adalah berkisar antara 100 sampai 200 responden, maka jumlah sampel tersebut telah terpenuhi

\section{HASIL}

\section{Aktivitas Operasional}

Kapal perikanan yang datang ke PPN Kejawanan terdiri atas kapal-kapal yang bertujuan antara lain: untuk bongkar/pendaratan hasil tangkapan ikan, mengisi perbekalan, per- baikan/docking, istirahat serta kapal-kapal yang berlindung saat gelombang besar. Frekuensi kunjungan kapal perikanan di PPN Kejawanan pada tahun 2019 sejumlah 434 kali. Jumlah ini mengalami peningkatan $17 \%$ dibandingkan dengan frekuensi kunjungan kapal pada tahun 2018 dengan jumlah kunjungan 371 kali (Gambar 1). Hal ini dipengaruhi oleh bertambahnya jumlah kapal domisili PPN Kejawanan pada tahun 2019. Frekuensi kunjungan kapal berdasarkan jenis alat penangkap ikan pada tahun 2019 masih didominasi oleh kapal dengan alat penangkap ikan (API) bouke ami yakni sejumlah 262 kali kunjungan atau 60,4\% dari total jumlah kunjungan kapal pada tahun 2018. Jumlah tersebut mengalami peningkatan apabila dibandingkan dengan jumlah kunjungan tertinggi pada tahun 2018 yang juga bouke ami (sebanyak 197 kali). Hal ini disebabkan oleh bergantinya jenis alat penangkap ikan dan ukuran kapal setelah program dari pemerintah untuk pelaksanaan pengukuran ulang kapal.

Berdasarkan klasifikasi ukuran GT, frekuensi kunjungan kapal tertinggi di PPN Kejawanan selama tahun 2019 didominasi oleh kapal dengan ukuran $\geq 51$ GT sebanyak 51,6\%. Frekuensi kunjungan kapal tertinggi terjadi pada bulan Oktober yaitu 55 kali. Hal ini karena banyak kapal datang setelah trip penangkapan ikan kedua tahun 2019. Jumlah kapal yang mendaratkan hasil tangkapan pada tahun 2019 yakni 302 kali, mengalami peningkatan 7,1\% dibandingkan jumlah kapal yang melakukan kegiatan bongkar pada tahun 2018 yang sejumlah 282 kali (Gambar 1).

Berdasarkan dokumen laporan tahunan PPN Kejawanan (2019) menyebutkan bahwa jumlah kapal ikan yang melakukan pendaratan ikan jumlahnya dapat lebih banyak, namun sejak 19 Nopember 2019 kapal-kapal di PPN Kejawanan melakukan boikot tidak mau bongkar di PPN Kejawanan. Hal ini terkait dangan berlakunya Peraturan Wali Kota Cirebon Nomor 40 Tahun 2019 Tentang Perubahan Atas Peraturan Wali Kota Cirebon Nomor 57 Tahun 2011 Tentang Petunjuk Pelaksanaan Peraturan Daerah Kota Cirebon. Sehingga, berimbas kepada sampai dengan akhir tahun 2019 tidak ada kapal perikanan yang mendaratkan hasil tangkapannya di PPN Kejawanan.

Kapal domisili PPN Kejawanan mengalami kenaikan jumlah dan jenis API yang digunakan, dari 181 unit pada tahun 2018 menjadi 2019 unit pada tahun 2019, atau mengalami peningkatan 21\%. Jenis API bouke ami merupakan jenis alat penangkap ikan dominan, dengan jumlah 120 unit (55\% dari total kapal domisili tahun 2019). Berdasarkan klasifikasi GT 
nya, kapal-kapal di PPN Kejawanan berada pada kisaran 21-196 GT. Kapal ukuran 31-60 GT mendominasi sebanyak 43\% (94 unit kapal). Selain itu, terdapat 7 unit kapal andon di PPN Kejawanan dengan kisaran ukuran 20-30 GT

Produksi ikan yang didaratkan di PPN Kejawanan pada tahun 2019 mencapai 3.565,03 ton dengan rincian produksi per jenis alat penangkap ikan (API) seperti yang diilustrasikan pada Gambar 2. Gambar tersebut menunjukkan bahwa jaring insang hanyut dasar/liong bun sebesar 185,14 ton, jaring cumi/bouke ami sejumlah $1.794,08$ ton, pancing cumi sejumlah
462,28 ton, cast net sejumlah 935,94 ton, pukat cincin pelagis besar sejumlah 135,49 ton serta produksi pukat cincin pelagis kecil sebanyak 50,90 ton. Sementara itu, total produksi ikan yang didaratkan di PPN Kejawanan adalah 9.981 ton, angka tersebut sudah termasuk produksi ikan yang didatangkan dari luar pelabuhan. Bila dibandingkan dengan produksi pada tahun 2018, produksi ikan yang didaratkan di PPN Kejawanan mengalami penurunan sebesar $16,63 \%$ atau sebanyak 711,09 ton. Produksi ikan yang didaratkan di PPN Kejawanan dapat dilihat pada Gambar 3.

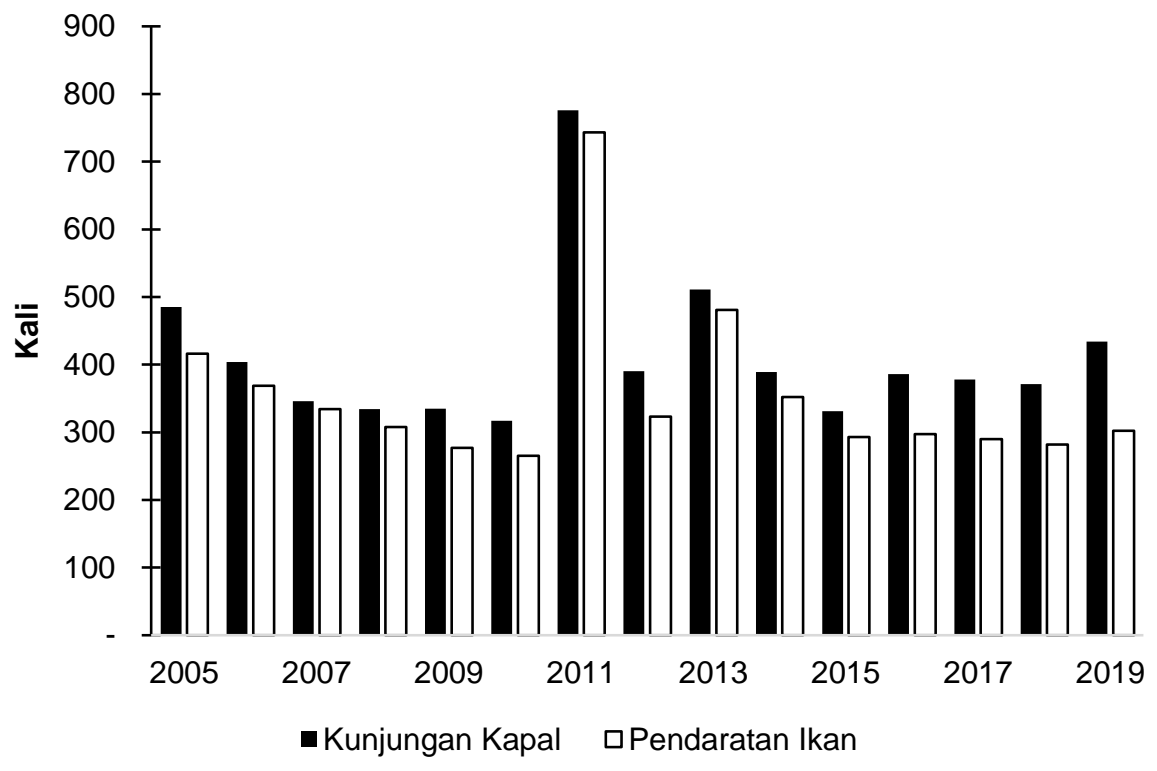

Gambar 1 Kunjungan dan Frekuensi Pendaratan Kapal Perikanan di PPN Kejawanan Tahun 2005 - 2019

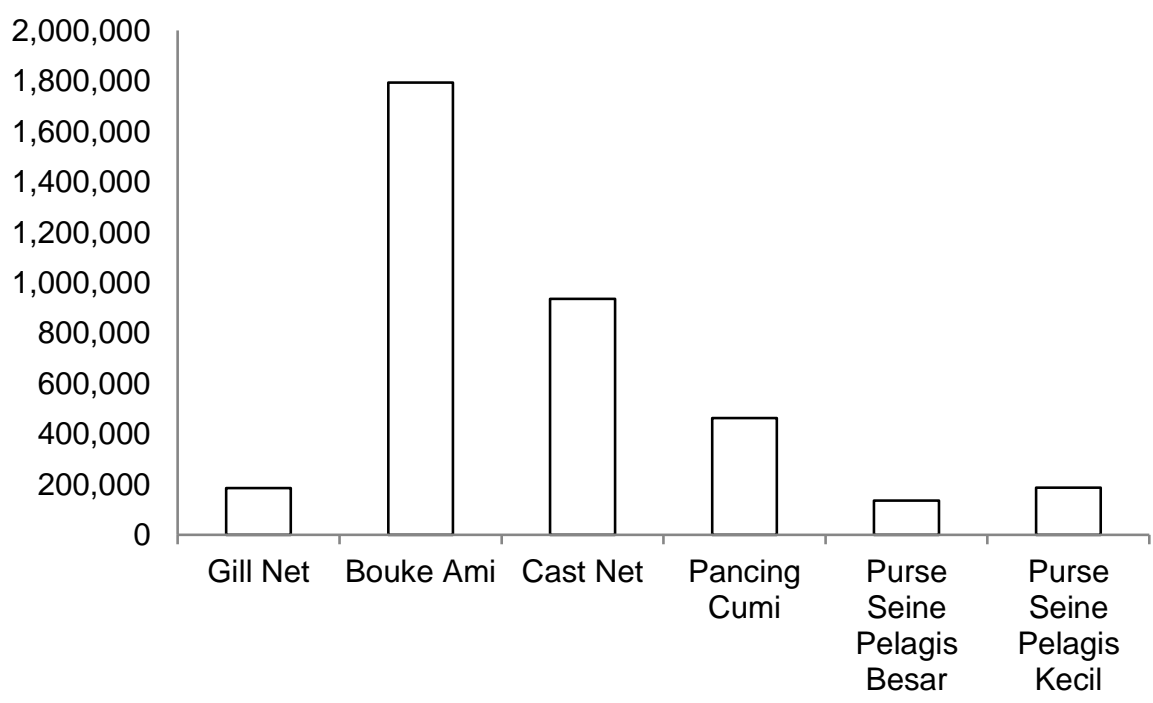

Gambar 2 Produksi Ikan per Jenis Alat Penangkap Ikan pada Tahun 2019 di PPN Kejawanan. 


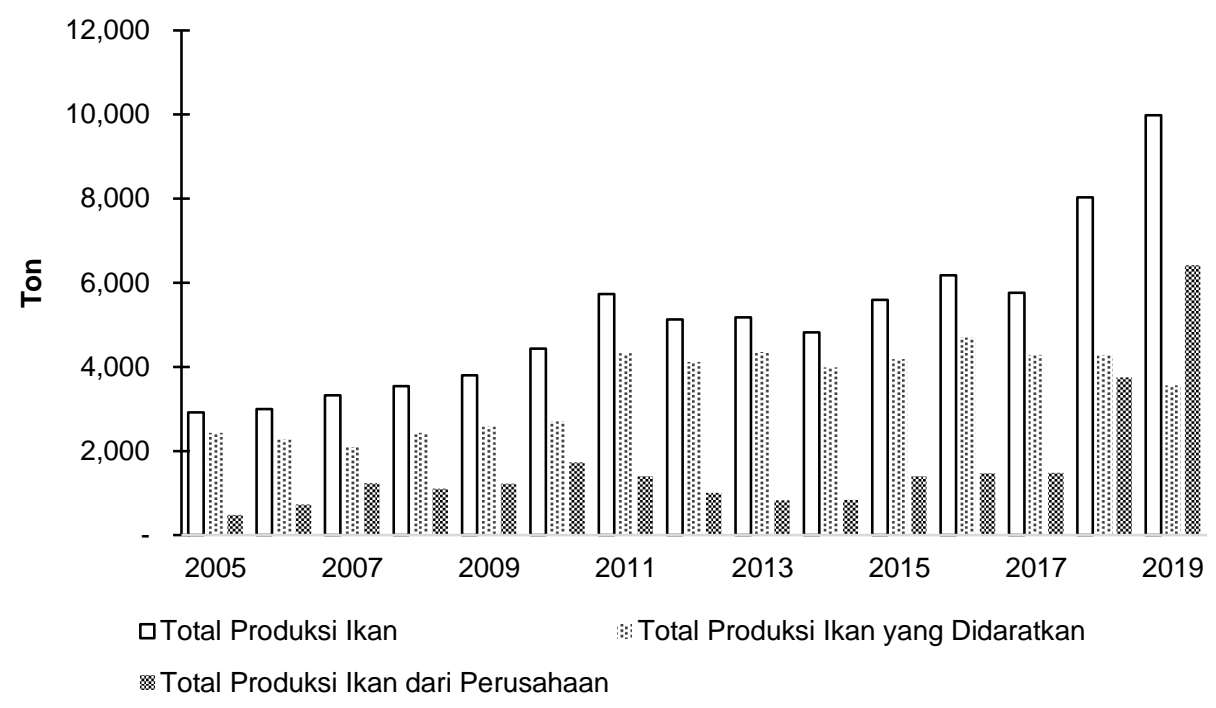

Gambar 3 Produksi ikan yang di daratkan di PPN Kejawanan dari Tahun 2005 - 2019.

\section{Nilai Produksi}

Nilai produksi ikan yang didaratkan di PPN Kejawanan pada tahun 2019 sejumlah Rp 147.301.194.670,-. Nilai produksi tersebut mengalami penurunan sebesar Rp 26.408.892.685,- dibandingkan tahun 2018.

Nilai produksi ikan yang didaratkan ditambah dengan nilai produksi ikan dari luar pelabuhan di PPN Kejawanan pada tahun 2019 yaitu $\mathrm{Rp}$ 608.433.860,-. Apabila dibandingkan dengan nilai produksi ikan pada tahun 2018 yang mencapai $\mathrm{Rp} 532.765 .235,-$, maka pada tahun 2019 nilai produksinya mengalami peningkatan sebesar $12,5 \%$. Nilai produksi mengalami perubahan setiap bulannya bahkan perharinya. Hal ini disebabkan oleh harga ikan yang berfluktuasi di lapangan, bergantung kepada jenis ikan, ketersediaan stok ikan, mutu ikan dan musim. Fluktuasi nilai produksi ikan dapat dilihat pada Gambar 4.

\section{Perbekalan}

Perbekalan kapal perikanan merupakan kelengkapan yang harus terpenuhi untuk operasional penangkapan ikan. Perbekalan untuk kapal perikanan mencakup BBM, air tawar bersih, bahan makanan, es dan umpan. Namun es bukan merupakan konsumsi untuk perbekalan kapal perikanan di PPN Kejawanan karena kapal-kapal perikanan di PPN Kejawanan sudah dilengkapi dengan freezer sehingga tidak membutuhkan es untuk menjaga kualitas ikan hasil tangkapan. Begitu pula dengan umpan, API yang digunakan kapal-kapal perikanan di PPN Kejawanan yaitu bouke ami, gillnet liong bun, gillnet oseanik, dan purse seine tidak memanfaatkan umpan.

\section{Penyaluran Air Tawar Bersih}

Jumlah air bersih yang disalurkan di PPN Kejawanan pada tahun 2019 sebanyak 4.075.000 liter, atau mengalami peningkatan $48,5 \%$ apabila dibandingkan dengan penyaluran air pada 2018 yang hanya 2.745.000 liter. Pada tahun 2019 tercatat 452 kapal mendapatkan pelayanan jasa pengisian perbekalan air bersih (Gambar 5).

\section{Perbekalan Bahan Makanan}

Perbekalan bagi kapal-kapal yang hendak melaut mencakup keperluan pangan Anak Buah Kapal (ABK), bahan bakar minyak dan stok air tawar bersih. Keperluan perbekalan untuk melaut bagi kapal-kapal perikanan, khususnya bahan pangan yang digunakan untuk memenuhi kebutuhan pangan perkapalnya sebagian besar diperoleh dari luar kawasan pelabuhan dan selama ini telah difasilitasi oleh pemilik atau pengurus kapal.

\section{Bahan Bakar Minyak (BBM)}

PPN Kejawanan melayani pengisian BBM subsidi dan non subsidi untuk kapal perikanan. Pada Januari 2019 terdapat tiga penyalur BBM resmi di PPN Kejawanan, namun sejak dilaksanakan pasar bebas di PPN Kejawanan mulai bulan November 2019, jumlah penyalur BBM yang dapat melayani kebutuhan perbekalan kapal perikanan tidak dibatasi. Berdasarkan data yang dihimpun, diketahui bahwa saat penelitian dilakukan terdapat 6 penyalur BBM di PPN Kejawanan. Jumlah ini dapat terus bertambah selama penyalur BBM memenuhi persyaratan yang ditetapkan oleh pihak PPN 
Kejawanan, salah satunya yaitu adanya faktur pajak dan pakta integritas. Pelayanan rekomendasi BBM bersubsidi mengacu kepada Perpres No. 191 Tahun 2014. Pada tahun 2019 penyaluran BBM di PPN Kejawanan mencapai 8.762 ton, meningkat signifikan dari tahun 2018 yang hanya mencapai 4.883 ton (Gambar 6).

Masyarakat nelayan adalah masyarakat yang hidup, tumbuh berusaha dan berkembang di kawasan pesisir, yakni suatu kawasan transisi antara wilayah darat dan laut. Jumlah nelayan yang melakukan aktivitas dalam kurun 2005 hingga 2019 dapat dilihat pada Gambar 7, yang menunjukkan bahwa jumlah nelayan terbesar diperoleh pada tahun 2019 dan terkecil pada tahun 2007.

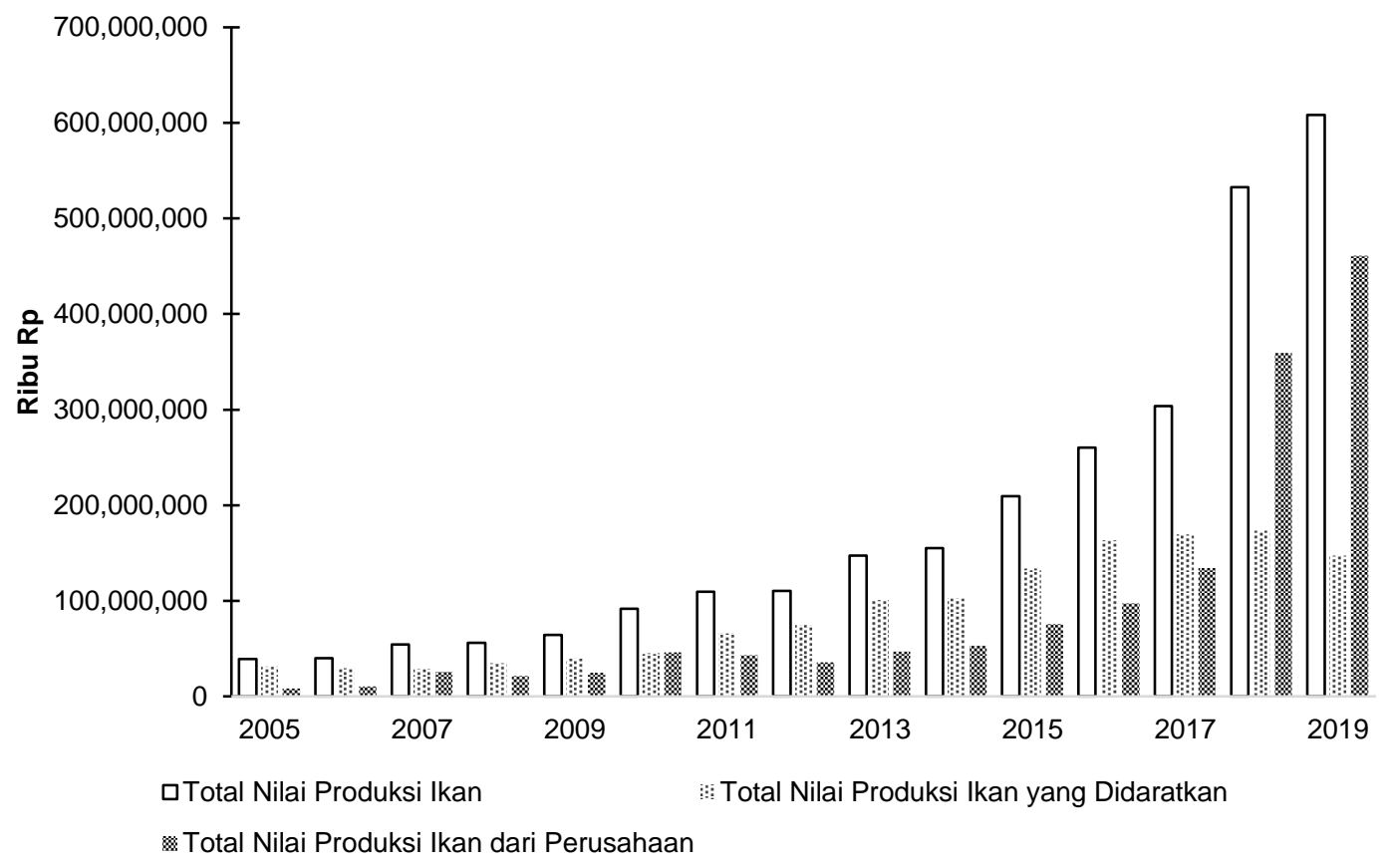

Gambar 4 Nilai Produksi Ikan di PPN Kejawanan dari Tahun 2005 - 2019.

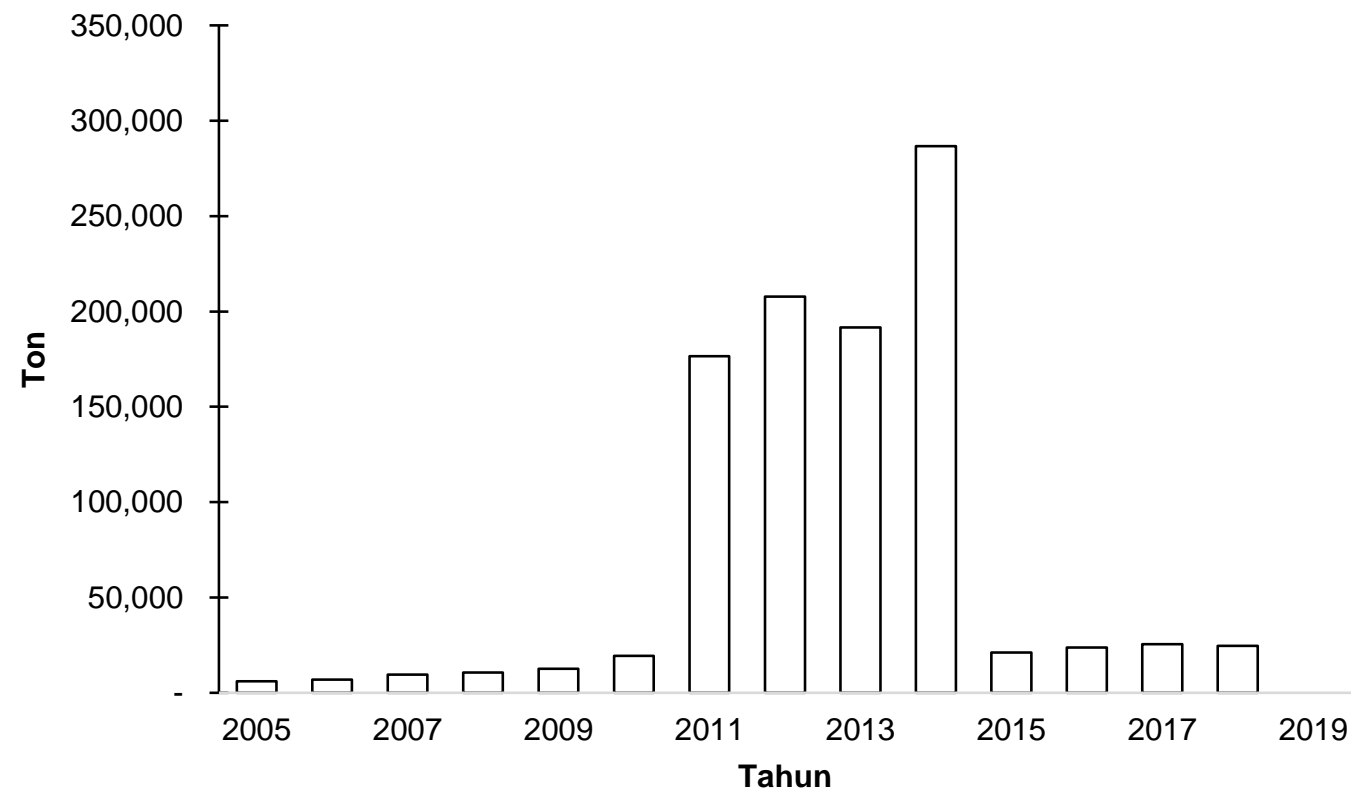

Gambar 5 Penyaluran air bersih di PPN Kejawanan dari Tahun 2005 - 2019. 


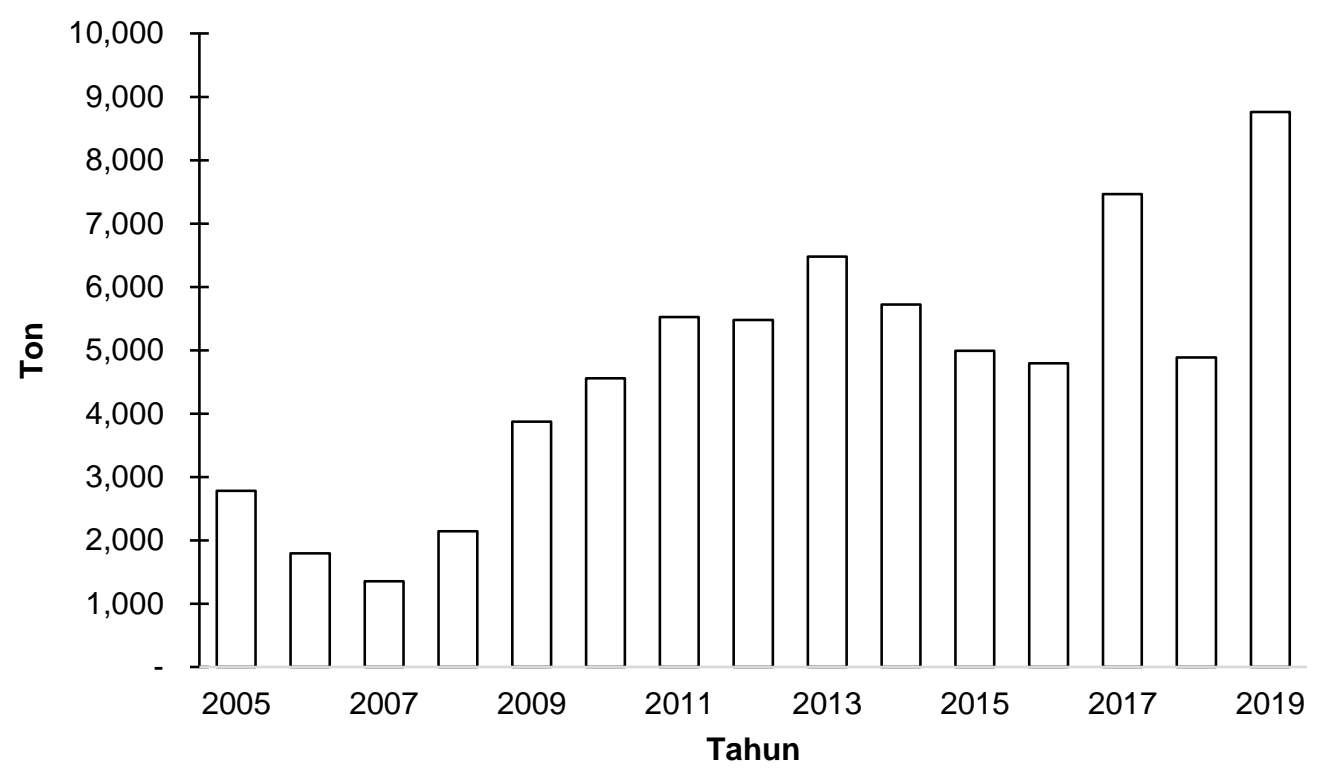

Gambar 6 Penyaluran BBM di PPN Kejawanan dari Tahun 2005 - 2019.

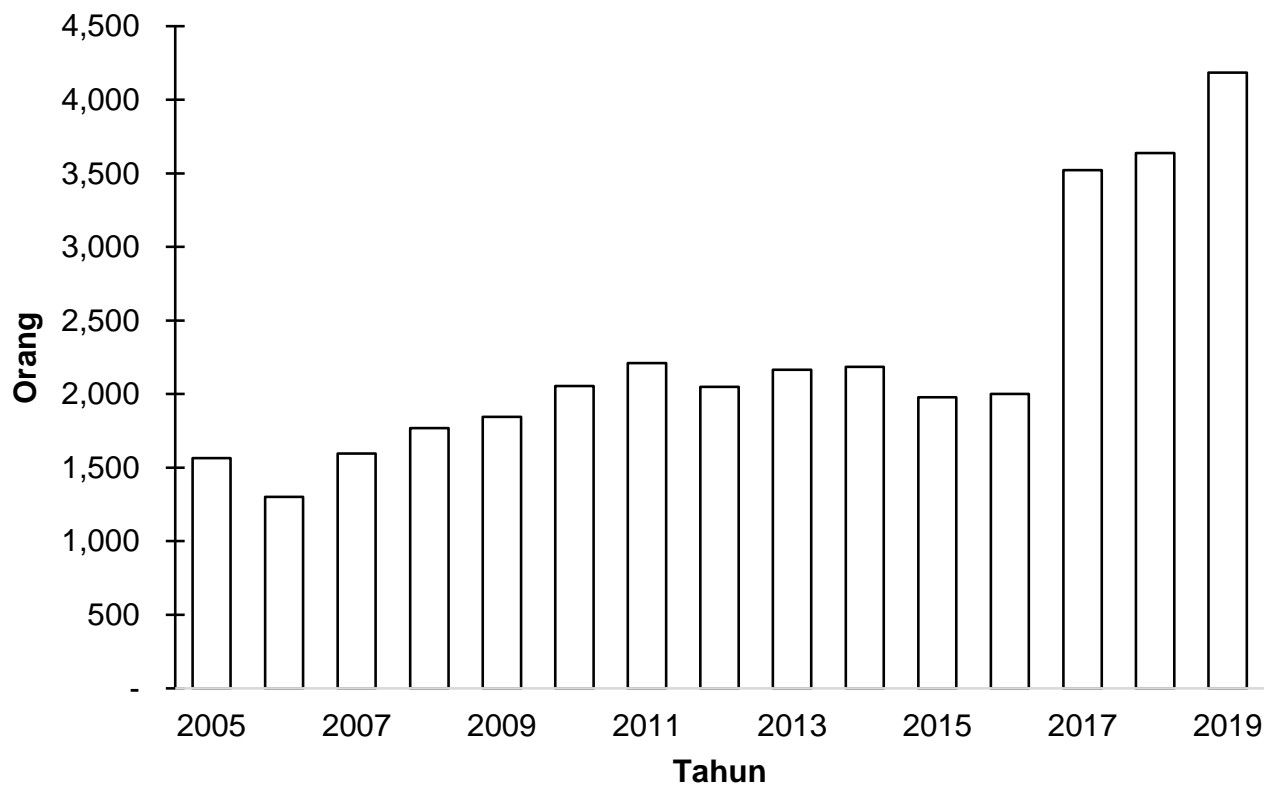

Gambar 7 Perkembangan Nelayan di PPN Kejawanan dari Tahun 2005 - 2019

Nilai Kinerja Operasional Untuk Parameter Direktorat Jenderal Perikanan Tangkap

Hasil penilaian kinerja operasional di PPN Kejawanan bulan Oktober 2019-Maret 2020 berpedoman pada Keputusan Direktur Jenderal Perikanan Tangkap Nomor 20/KEPDJPT/ 2015 disajikan pada Tabel 1. Penilaian kinerja terhadap 27 kriteria tersebut menunjukkan bahwa kinerja operasional PPN Kejawanan berkisar antara 70,25-86,50. Secara umum, selama periode Oktober 2019 hingga Maret 2020 pelabuhan menunjukkan kinerja yang baik, sementara itu hasil penilaian kinerja sangat baik diperoleh pada bulan November 2019.

\section{Faktor-Faktor Kinerja PPN Kejawanan}

Model path diagram menggambarkan adanya modifikasi model untuk mencapai model yang fit (Gambar 8). Dalam model tersebut digambarkan pengaruh setiap indikator yang membentuk definisi operasio-nal variabel sebagaimana tersaji pada Tabel 2. Kemudian dilakukan analisis faktor konfirmatori konstruk Full Model yang menunjukkan 
bahwa model tersebut telah memenuhi kriteria fit (Tabel 3), hal ini ditandai dengan nilai hasil perhitungan terhadap tiap-tiap indeks goodness-of-fit yang telah memenuhi kriteria yang ditentukan. Hasil pengujian hipotesis dapat dilihat pada Tabel 4, semua hipotesis diterima kecuali $\mathrm{H} 6$ Kebijakan pemerintah berpengaruh positif dan signifikan kinerja PPN.

Berdasarkan hasil pengujian regression weight pada Tabel 4 menggambarkan bahwa $\mathrm{H}_{1}, \mathrm{H}_{2}, \mathrm{H}_{3}, \mathrm{H}_{4}, \mathrm{H}_{5}, \mathrm{H}_{6}, \mathrm{H}_{7}$, dan $\mathrm{H}_{8}$ dinyatakan diterima, karena memiliki nilai Critical Ratio (C.R.) di atas 1,96 dan Probabilitas di bawah 0,05. H6 dinyatakan ditolak karena nilai Critical Ratio (C.R.) di bawah 1,96 dan Probabilitas di atas 0,05. Selanjutnya untuk mengetahui besarnya nilai pengaruh setiap indikator atau dimensi pembentuk masing-masing variabel laten dan pengaruh antar variabel dapat dianalisis dengan koefisien standardized pada hasil uji standardized regression weights konstruk full model pada Tabel 5.

Model persamaan struktural berdasarkan hasil tersebut dapat ditulis sebagai berikut:

$\begin{array}{lll}\text { Variabel } & = & \text { Variabel Eksogen }+ \\ \text { Endogen } & \text { Error } \\ \text { Internal } & =, 211 \text { Kebijakan } \\ & & \text { Pemerintah }+0,045 \zeta\end{array}$

$$
\begin{array}{ll}
\text { Pelayanan }= & 0,713 \text { Internal }+0,212 \\
\text { PPN } & \text { Eksternal }+0,570 \zeta \\
\text { Kebijakan }= & 0,273 \text { Eksternal }+ \\
\text { Pemerintah }= & 0,075 \zeta \\
\text { Kinerja PPN } \quad & 0,410 \text { Internal }+0,195 \\
& \text { Eksternal }+0,411 \\
& \text { Pelayanan PPN }- \\
& 0,212 \text { Kebijakan } \\
& \text { Pemerintah }+0,619 \zeta
\end{array}
$$

Berdasarkan Tabel 5 dan persamaan model tersebut dapat dilihat bahwa setiap indikator atau dimensi pembentuk masingmasing variabel laten memiliki pengaruh positif dan negatif dengan hasil koefisien standardized dari terendah 0,211 hingga tertinggi 0,713. Selanjutnya, dalam hubungan antar variabel dapat diketahui bahwa pengaruh terbesar adalah pengaruh variabel Internal terhadap variabel Pelayanan dengan koefisien standaridized 0,713, yang artinya ketika variabel Internal naik 1, maka akan menaikkan variabel Pelayanan sebesar 0,659 . Variabel terbesar yang mempengaruhi variabel Kinerja adalah variabel Internal dengan koefisien standaridized 0,410, yang artinya ketika variabel Internal naik 1 maka akan menaikkan variabel Kinerja sebesar 0,410 . Selain itu, variabel Kebijakan Pemerintah berpengaruh negatif dan signifikan terhadap variabel Kinerja PPN dengan koefisien standaridized -0,212, yang artinya ketika variabel Kebijakan Pemerintah naik 1 maka akan menurunkan variabel Kinerja PPN sebesar 0,212.

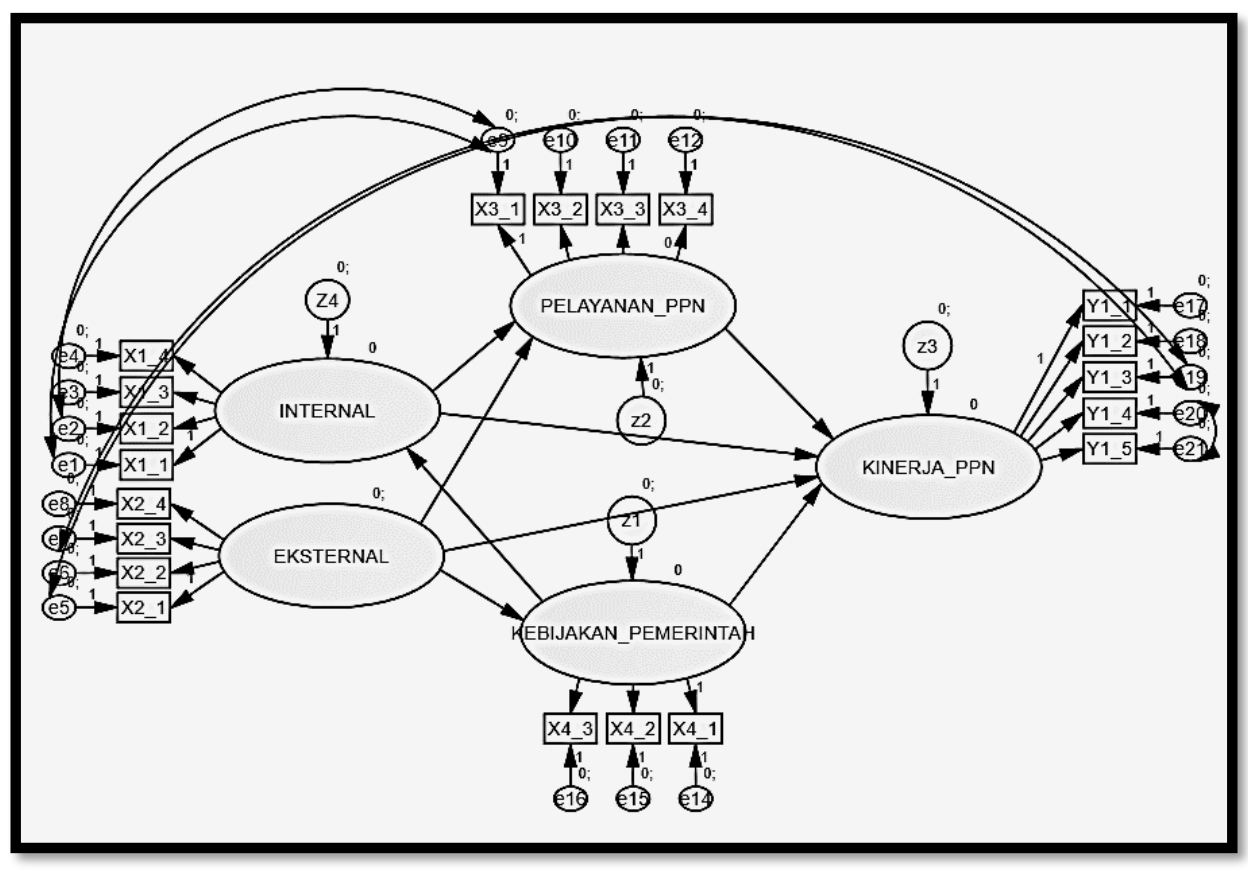

Gambar 8 Model Path Diagram 


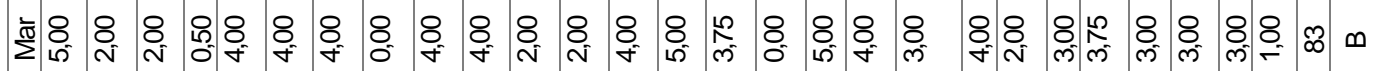

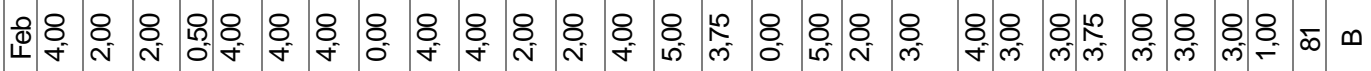

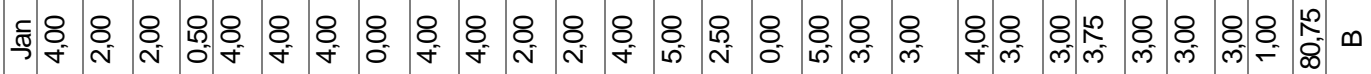

产

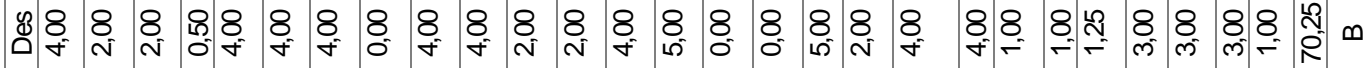

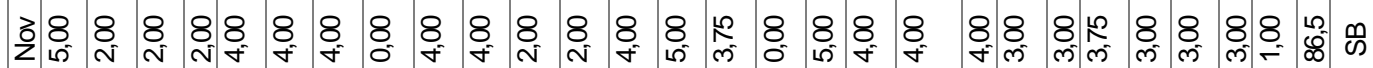

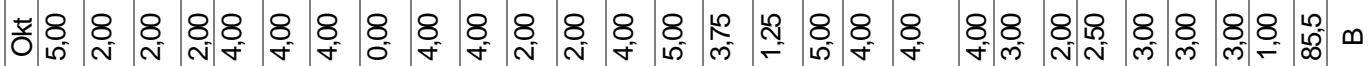

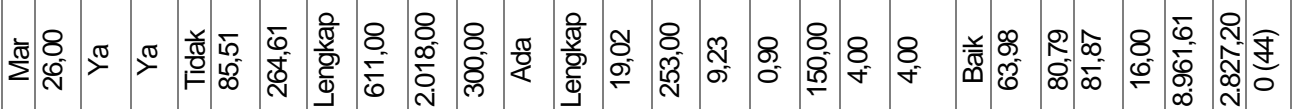

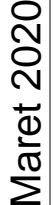

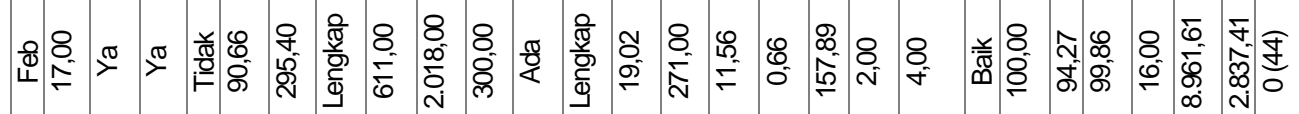

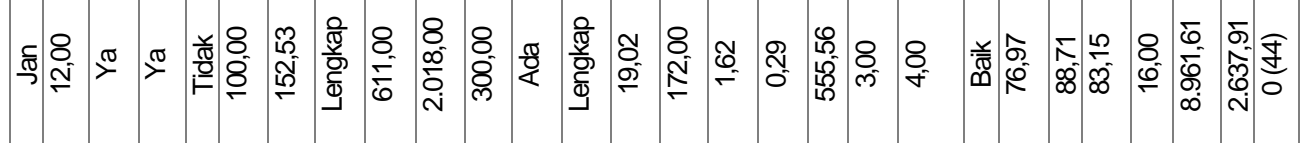

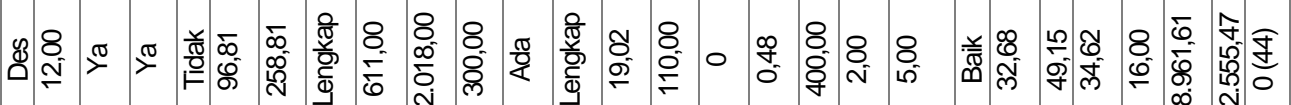

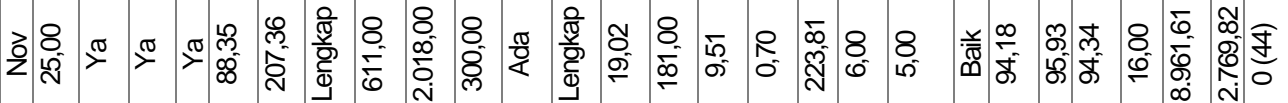

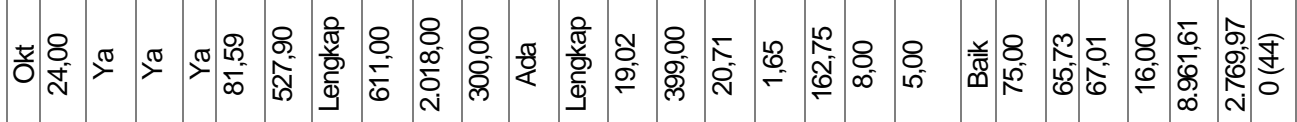
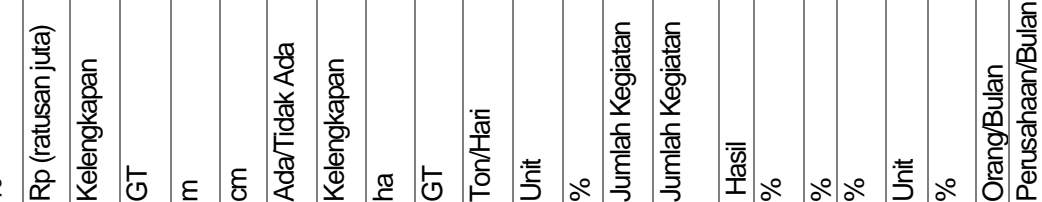

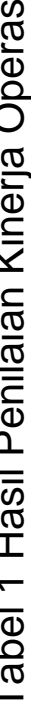

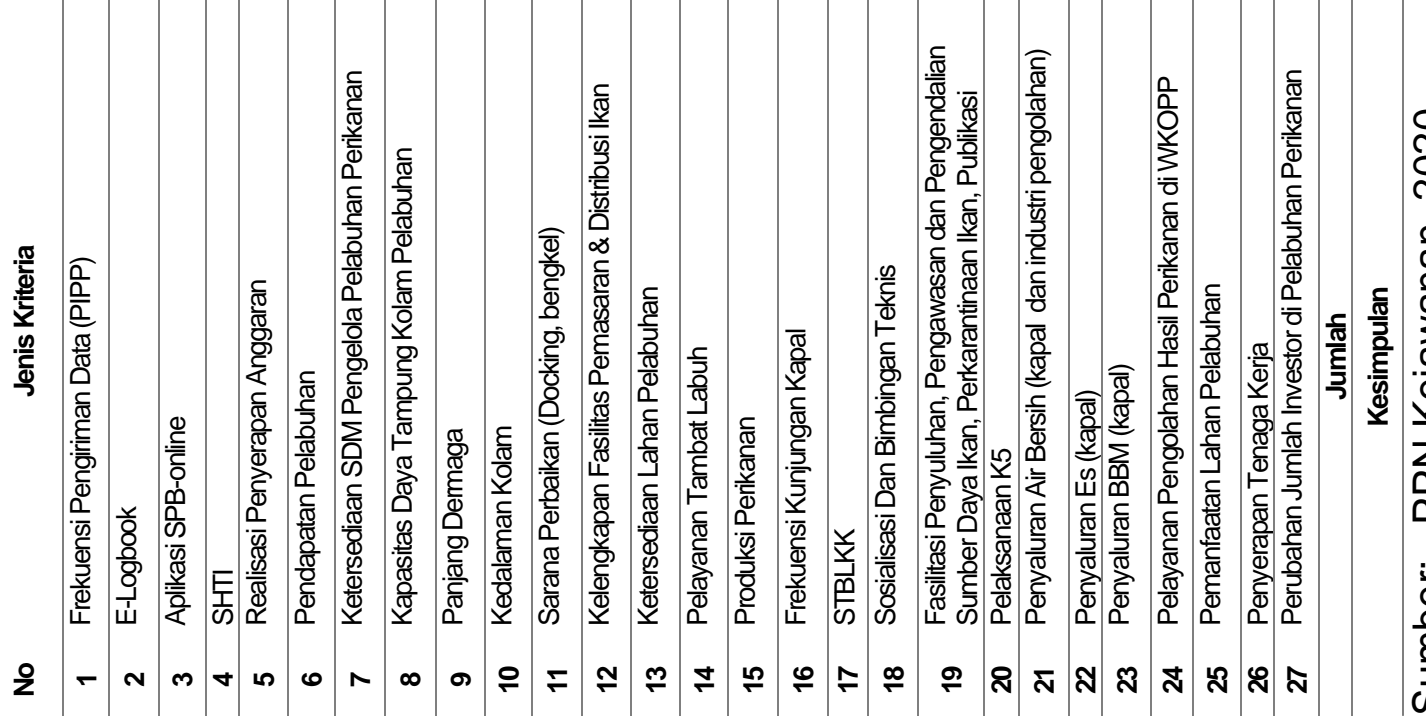

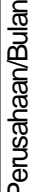


Tabel 2 Defenisi Operasional Variabel

\begin{tabular}{|c|c|c|}
\hline No & Kode & Indikator \\
\hline \multicolumn{3}{|r|}{ Internal } \\
\hline 1 & $\mathrm{X} 1 \_1$ & Pengelola PPN (pendidikan, ketrampilan, budaya kerja). \\
\hline 2 & $\mathrm{X} 1 \_2$ & Ketersediaan Anggaran PPN \\
\hline 3 & X1_3 & Nelayan/Pengolah/Pemasar (pendidikan, ketrampilan, pengalaman) \\
\hline 4 & $\times 14$ & Produktivitas Nelayan/Pengolah/Pemasar (teknologi, pendapatan, produksi) \\
\hline \multicolumn{3}{|r|}{ Eksternal } \\
\hline 5 & $\mathrm{X} 2 \_1$ & Sumberdaya Ikan (Fishing Ground) \\
\hline 6 & $\mathrm{X} 2 \_2$ & Pasar \\
\hline 7 & $x 23$ & Kondisi Ekonomi \\
\hline 8 & $\times 24$ & Perkembangan Teknologi \\
\hline \multicolumn{3}{|r|}{ Pelayanan } \\
\hline 9 & X3_1 & Pelayanan Produksi \\
\hline 10 & X3_2 & Pelayanan Industri Perikanan \\
\hline 11 & X3_3 & Pelayanan Processing \\
\hline 12 & X3 4 & Pelayanan Pemasaran \\
\hline \multicolumn{3}{|r|}{ Kebijakan Pemerintah } \\
\hline 13 & X4_1 & UU / Peraturan Pemerintah/Peraturan Menteri \\
\hline 14 & X4_2 & Otonomi Daerah/Peraturan Gubernur/Peraturan Bupati \\
\hline 15 & $\mathrm{X} 4 \_3$ & Pelaksanaan/Kerja sama PPN \\
\hline \multicolumn{3}{|r|}{ Kinerja PPN } \\
\hline 16 & Y1_1 & Kesejahteraan Nelayan \\
\hline 17 & Y1_2 & Pengembangan Usaha \\
\hline 18 & Y1_5 & Pajak/PNBP \\
\hline 19 & Y1_6 & Produktivitas Kerja \\
\hline 20 & Y1_7 & Tingkat Penyerapan Tenaga Kerja (Nelayan, Pemasar dan Pengolah, Buruh) \\
\hline
\end{tabular}

Sumber: Data primer yang diolah, 2020

Tabel 3 Hasil Uji Model Faktor Konfirmatori Konstruk Full Model

\begin{tabular}{cccc}
\hline Kriteria & Cut off Value & Hasil & Evaluasi Model \\
\hline & Kecil; $\mathrm{X}^{2}$ dengan $\mathrm{df}$ & \\
Chi-square & & & \\
CMIN/DF & $215, \mathrm{p}: 5 \%=250.207$ & 238,655 & Cukup \\
GFI & $<2,00$ & & \\
RMSEA & Mendekati 1,0 & 1,520 & Baik \\
AGFI & $\leq 0,08$ & 0,855 & Baik \\
PNFI & Mendekati 1,0 & 0,062 & Baik \\
PGFI & $>0,50$ & 0,806 & Baik \\
& $\geq 0,50$ & 0,693 & Baik \\
\hline
\end{tabular}

Sumber: Data primer yang diolah, 2020

Tabel 4 Regression Weight

\begin{tabular}{clccc}
\hline $\mathrm{NO}$ & \multicolumn{1}{c}{ HIPOTESIS } & CR & $\mathrm{P}$ & KETERANGAN \\
\hline $\mathrm{H}_{1}$ & $\begin{array}{l}\text { Internal berpengaruh positif dan signifikan terhadap } \\
\text { pelayanan PPN }\end{array}$ & 5,207 & 0,000 & Diterima \\
$\mathrm{H}_{2}$ & $\begin{array}{l}\text { Kebijakan pemerintah berpengaruh positif dan signifikan } \\
\text { terhadap internal }\end{array}$ & 1,999 & 0,046 & Diterima \\
$\mathrm{H}_{3}$ & $\begin{array}{l}\text { Eksternal berpengaruh positif dan signifikan terhadap } \\
\text { pelayanan PPN }\end{array}$ & 2,413 & 0,016 & Diterima \\
$\mathrm{H}_{4}$ & $\begin{array}{l}\text { Eksternal berpengaruh positif dan signifikan terhadap } \\
\text { kebijakan pemerintah }\end{array}$ & 2,772 & 0,006 & Diterima \\
$\mathrm{H}_{5}$ & $\begin{array}{l}\text { Pelayanan PPN berpengaruh positif dan signifikan } \\
\text { kinerja PPN }\end{array}$ & 2,629 & 0,009 & Diterima \\
$\mathrm{H}_{6}$ & $\begin{array}{l}\text { Kebijakan pemerintah berpengaruh positif dan signifikan } \\
\text { kinerja PPN }\end{array}$ & $-2,739$ & 0,006 & Ditolak \\
$\mathrm{H}_{7}$ & $\begin{array}{l}\text { Internal berpengaruh positif dan signifikan terhadap } \\
\text { kinerja PPN }\end{array}$ & 2,420 & 0,016 & Diterima \\
$\mathrm{H}_{8}$ & $\begin{array}{l}\text { Eksternal berpengaruh positif dan signifikan terhadap } \\
\text { kinerja PPN }\end{array}$ & 2,284 & 0,022 & Diterima \\
\hline
\end{tabular}

Sumber: Data primer yang diolah, 2020 
Tabel 5 Hasil Uji Standardized Regression Weights Konstruk Full Model

\begin{tabular}{lllr}
\hline & & & Estimate \\
\hline Kebijakan_Pemerintah & $<--$ & Eksternal & 0,320 \\
Internal & $<--$ & Kebijakan_Pemerintah & 0,467 \\
Pelayanan_PPN & $<--$ & Internal & 0,659 \\
Pelayanan_PPN & $<---$ & Eksternal & 0,157 \\
Kinerja_PPN & $<--$ & Kebijakan_Pemerintah & 0,178 \\
Kinerja_PPN & $<---$ & Pelayanan_PPN & 0,260 \\
Kinerja_PPN & $<---$ & Internal & 0,334 \\
Kinerja_PPN & $<---$ & Eksternal & 0,309 \\
\hline
\end{tabular}

\section{PEMBAHASAN}

Aktivitas operasional PPN Kejawanan sangat dinamis dari tahun ke tahun (Gambar 1 sampai Gambar 7) dan diharapkan dapat mengemban dan mengimplementasikan tugas pokok dan fungsinya sehingga mengarah kepada terwujudnya pusat pertumbuhan, pengembangan ekonomi perikanan berbasis perikanan tangkap, perbantuan pelayanan publik dan kesyahbandaran perikanan di Cirebon. Kondisi PP hingga saat ini merupakan infrastruktur yang dibangun pemerintah dengan orientasi pelayanan kepada para penguna pelabuhan guna memperlancar kegiatan pemasaran produk perikanan dengan harapan kesejahteraan nelayan dapat terwujud (Muninggar 2008). Kunjungan kapal sangat terkait dengan tingkat produksi dan nilai produksi. Tingginya produksi ikan yang didaratkan maka semakin ramai pula kegiatan yang terjadi di pelabuhan tersebut, sehingga kinerja operasionalnya akan meningkat pula (Ngamel et al. 2013). Lebih lanjut Nugraha et al. (2019) bahwa kegiatan penangkapan di Cirebon masih didominasi oleh nelayan tradisional.

Hasil analisis SEM menunjukkan bahwa variabel Internal PPN Kejawanan mempunyai pengaruh paling besar terhadap variabel Kinerja PPN Kejawanan (Gambar 8 dan Tabel 5). Hal ini menunjukkan bahwa semakin tinggi perbaikan ataupun transformasi di Internal (pengelola PPN, nelayan, anggaran dan produktivitas) PPN Kejawanan maka semakin baik pula Kinerja PPN Kejawanan (SDM pengelola, nelayan). Berdasarkan hal tersebut, manajemen PPN diharapkan fokusnya melakukan transformasi internal/transformasi budaya untuk meningkatkan kinerja dan perbaikan kualitas pelayanan produksi, pelayanan industri perikanan, pelayanan processing, pelayanan pemasaran dan pelayanan distribusi. Apabila hal ini dilakukan dengan baik oleh manajemen PPN, maka kinerja akan meningkat. Hal tersebut sejalan dengan penelitian Obi (2015) bahwa semua sumber daya seperti uang atau anggaran, bahan, teknologi dan metode, sama pentingnya tetapi sumber daya manusia adalah yang terpenting karena faktor itulah yang memberikan kehidupan dan dinamisme kepada faktor-faktor produksi lainnya. Orangorang di dalam organisasi memberikan bakat, keterampilan, dan upaya yang sangat menentukan pada keberhasilan kinerja organisasi mana pun. Organisasi yang lebih sukses adalah organisasi di mana orang atau sumber daya manusia menjadi fokus utama manajemen. Begitu pula disebutkan oleh Fadhil (2016) bahwa pengetahuan, keterampilan, dan sikap adalah komponen kompetensi yang merupakan kunci dalam manajemen yang memainkan peran penting dan strategis dalam meningkatkan prestasi kerja pegawai.

Kompetensi karyawan semakin penting manfaatnya, karena sumber daya manusia adalah harta atau aset berharga yang dimiliki perusahaan dan juga yang menentukan keberhasilan perusahaan untuk mencapai tujuan. Kinerja perusahaan sangat bergantung pada bagaimana cara menemukan orang yang tepat untuk bekerja untuk mereka, untuk membimbing karyawan yang dipilih dan untuk memastikan kebutuhan mereka (Jashari dan Kutllovci 2020; Anderson et al. 2014). Organisasi harus memprioritaskan pengembangan elemen manusia untuk memaksimalkan bakat, keterampilan dan kemampuan yang secara otomatis akan mencerminkan keuntungan perusahaan (Okoye dan Ezejiofor 2013; Wright et al. 2013; Villajos et al. 2019; Arulrajah 2017)

Upaya untuk meningkatkan kualitas layanan harus didasarkan pada pendekatan profesional dalam manajemen operasi, khususnya di bidang pengembangan sumber daya manusia (Chand 2010; Shen dan Zhu 2011; Adil 2015). Sementara itu, Diniah et al. (2012) menyatakan bahwa keunggulan suatu pelayanan bergantung pada keunikan dan kualitas yang diperlihatkan oleh pelayanan tersebut. Perubahan dan perkembangan 
teknologi yang cepat telah menyebabkan semua organisasi menghadapi persaingan yang ketat. Untuk menjaga kelangsungan bisnis dalam lingkungan yang kompetitif serta untuk memaksimalkan produktivitas dan pendekatan bisnis-sentris ke industri, ekonomi berbasis pengetahuan dan bisnis telah mengubah kebijakan organisasi terhadap karyawannya. Pengembangan tenaga kerja berkinerja tinggi diberikan untuk meningkatkan kemampuan bersaing. Kegiatan tersebut meliputi; pengembangan manajemen sumber daya manusia, pengembangan staf berkualitas, pelatihan untuk tujuan bisnis, peningkatan motivasi, evaluasi, serta melakukan pendekatan strategis dan koheren dengan karyawan (Ozkeser 2019).

Variabel keandalan memberikan pengaruh yang signifikan terhadap kelancaran operasional penangkapan ikan. Empat indikator dari variabel keandalan, yaitu: 1) penyediaan BBM bersubsidi untuk kebutuhan operasional penangkapan di kawasan pelabuhan; 2) keoptimalan pelayanan yang diberikan pihak UPTD kepada nelayan; 3) penyediaan es di kawasan pelabuhan; dan 4) penyediaan air untuk kebutuhan operasional penangkapan di kawasan pelabuhan, menunjukkan bahwa rata-rata tingkat kepuasan responden terhadap variabel keandalan berada pada tingkat kepuasan rendah (Rahmah et al. 2018). Dalam kenyataannya praktek manajemen (management practices) tidak selalu mudah dan berhasil untuk mempengaruhi orang agar berkerja lebih produktif. Globalisasi makin menyadarkan orang untuk lebih memperhatikan faktor budaya bangsa, budaya nasional dan akhirnya budaya perusahaan dalam sesbuah praktek mangemen (Biantoro 2002).

Transformasi internal untuk meningkatkan kinerja dan perbaikan kualitas pelayanan produksi, pelayanan industri perikanan, pelayanan processing, pelayanan pemasaran dan pelayanan distribusi berorientasi kepada pemenuhan kebutuhan pelanggan. Hal tersebut dapat diwujudkan melalui pengelolaan PP dengan memperhatikan beberapa hal sebagai berikut:

1. Selalu bertindak mendekatkan diri kepada masyarakat terutama pelanggan dengan cara: (a) menanyakan apa yang harus dibantu, (b) mendengarkan saran-saran mereka, (c) mendorong agar masyarakat mencoba memanfaatkan pelayanan instansi pemerintah tanpa kecurigaan.

2. Secara terus menerus selalu meningkatkan mutu pelayanan (pendekatan mutu terpadu), dengan memberikan nilai tambah (benefit, impact).

a) Menempatkan masyarakat sebagai pengemudi organisasi;

b) Mengubah perhatian aparatur pemerintah dari berorientasi kepada birokrasi menjadi selalu berorientasi untuk memenuhi kebutuhan masyarakat;

Secara umum pelayanan di pelabuhan perikanan dapat dibedakan ke dalam dua kategori. Kategori yang pertama adalah pelayanan yang bersifat langsung kepada nelayan/pengusaha perikanan untuk menyediakan barang/jasa yang mereka butuhkan. Sementara itu, kategori yang kedua adalah pelayanan kepada masyarakat umum di dalam pelabuhan menggunakan metodologi yang lebih bersifat massal (nelayan serta para pengusaha perikanan) agar lebih mampu memajukan usahanya dengan menggunakan berbagai fasilitas yang tersedia di PP (Murdiyanto 2004).

Pelayanan untuk memenuhi keperluan pengguna jasa pelabuhan bersifat langsung dan kasuistis dalam arti dilakukan secara kasus demi kasus. Pelayanan langsung sering memerlukan tenaga yang memiliki keterampilan tertentu (listrik, las, mesin diesel dan lain sebagainya) karena perhatian utama adalah supaya apa yang dikehendaki oleh pengguna jasa dapat segera dipenuhi dengan sebaik-baiknya (prima). Pelayanan yang diperlukan meliputi berbagai kegiatan mulai dari sarana produksi, pemasaran hasil sampai dengan distribusinya. Tenaga yang melakukan pelayanan dituntut memiliki keahlian tertentu yang diperkuat melalui suatu bentuk surat keterangan/sertifikat. Hal ini dimaksudkan agar dapat selalu dilakukan penjenjangan/akreditasi untuk mempertahankan atau meningkatkan keterampilan tersebut. Dengan demikian, pemberian pelayanan umum oleh PP menjadi semakin prima. Maka, sertifikasi keterampilan juga dimaksudkan agar penyelenggaraan pelayanan tetap berdasarkan atas azas efisiensi serta tidak melanggar etika profesi (Murdiyanto 2004).

Pelayanan umum yang diberikan langsung kepada para pengguna jasa (dapat dilakukan oleh manajemen pelabuhan sendiri, atau oleh swasta, tetapi bisa oleh keduanya. Efisiensi ditempuh melalui tiadanya kemungkinan monopoli, tercipta iklim persaingan yang sehat. Berbagai ketentuan pelayanan umum harus jelas terbaca pada setiap tempat dimana masyarakat pengguna jasa sering berkumpul. Pengumumannya singkat dan tidak bersifat larangan serta mengandung 
segala persyaratan yang ditentukan untuk memperoleh pelayanan (Murdiyanto 2004).

Menurut Lubis et al. (2016) bahwa teori keagenan menjelaskan bahwa masalah manajemen laba diminimalkan dengan pemantauan melalui Good Corporate Governance dapat diterapkan di PP. Untuk meningkatkan kinerja manajemen dalam mengawasi atau memantau kinerja manajemen dengan tetap menjamin akuntabilitas manajemen kepada pemegang saham berdasarkan kerangka peraturan.

Menurut Yanti dan Yulisti (2011) Otonomi Daerah memberikan kebebasan bagi pemerintahan daerah kabupaten sebagai pemegang kekuasaan otonom untuk memilih menerapkan atau tidak menerapkan retribusi, semua tergantung pada kebijaksanaan pimpinan di daerah. Penerapan pungutan retribusi daerah untuk sektor kelautan dan perikanan menjadi salah satu masalah. Pendapatan yang diperoleh dari retribusi tersebut nantinya akan menjadi salah satu pendapatan asli daerah yang akan dipergunakan untuk membangun daerah. Berlakunya Peraturan Wali Kota Cirebon Nomor 40 Tahun 2019 tentang Perubahan Atas Peraturan Wali Kota Cirebon Nomor 57 Tahun 2011 tentang Petunjuk Pelaksanaan Peraturan Daerah Kota Cirebon telah menyebabkan tidak ada kapal perikanan yang mendaratkan hasil tangkapannya di PPN Kejawanan. Untuk itu perlu adanya komunikasi dan pendekatan segera ke pelaku usaha dari Pemerintah Kota Cirebon dan Internal PPN.

\section{KESIMPULAN}

Kesimpulan dari penelitian ini bahwa aktivitas operasional PPN Kejawanan terus mengalami peningkatan, baik frekuensi kunjungan, produksi dan nilai produksi ikan yang di daratkan, serta kinerja yang lebih baik. Penilaian kinerja terhadap 27 kriteria tersebut menunjukkan bahwa kinerja operasional PPN Kejawanan berkisar antara 70,25-86,50. Selama Oktober 2019 hingga Maret 2020 PPN Kejawanan berkinerja baik, bahkan November 2019 menunjukkan performa sangat baik. Berdasarkan hasil pengujian SEM variabel internal mempunyai pengaruh paling besar terhadap kinerja PPN. Dengan demikian, peningkatkan kualitas SDM/ pengelola PPN (pendidikan, ketrampilan dan budaya kerja), meningkatkan alokasi anggaran UPT, meningkatkan kualitas nelayan/- pengolah/pedagang (pendidikan, ketrampilan dan pengalaman), meningkatkan produktivitas Nelayan (teknologi, pendapatan dan produksi), akan meningkatan kinerja PPN Kejawanan.

\section{SARAN}

Internal PPN Kejawanan mempunyai pengaruh paling besar terhadap kinerja PPN Kejawanan. Untuk itu disarankan manajemen PPN Kejawanan melakukan Transformasi Budaya. Apabila hal ini dilakukan dengan baik oleh manajemen PPN, maka dapat meningkatkan kinerja PPN Kejawanan.

\section{UCAPAN TERIMA KASIH}

Ucapan terima kasih dan penghargaan diberikan kepada Kepala PPN Kejawanan dan Staf, yang telah membantu dalam penelitian ini. Terima kasih juga kepada editor dan pengelola Marine Fisheries Journal-Departemen Pemanfaatan Sumberdaya Perikanan FPIK IPB yang telah menelaah dan mereview naskah jurnal ini.

\section{DAFTAR PUSTAKA}

Adil MS. 2015. Strategic Human Resource Management Practices and Competitive Priorities of the Manufacturing Performance in Karachi. Global Journal of Flexible Systems Management. 16(1): 37-61.

Anderson N, Potočnik K, Zhou J. 2014. Innovation and Creativity in Organizations: A State-Of-Thescience Review, Prospective Commentary, and Guiding Framework. Journal of Management, 40(5): 1297-1333.

Arulrajah AA. 2017. Productivity and Quality Management through Human Resource Management: A Systematic Review. International Review of Management and Business Research. 6(2): 419-437.

Bayyinah AA, Solihin I, Wisudo SH. 2016. Kepuasan Nelayan Terhadap Pelayanan Pelabuhan Perikanan Nusantara (PPN) Kejawanan Cirebon. Marine Fisheries. 7(1): 33-43.

Biantoro U. 2002. Pengaruh Praktek Manajemen Sumber Daya Manusia Terhadap Budaya Organisasi dan 
Kinerja Perusahaan. [Disertasi thesis]. Universitas Airlangga, Surabaya.

Chand M. 2010. The Impact of HRM Practices on Service Quality, Customer Satisfaction and Performance in the Indian Hotel Industry. The International Journal of Human Resource Management. 21(4): 551-566.

Deng P, Lu S, Xiao H. 2013. Evaluation of the Relevance Measure between Ports and Regional Economy Using Structural Equation Modeling. Journal Transport Policy. 27: 123-133.

Diniah, Mochammad PS, Dede S. 2012. Pelayanan Pelabuhan Perikanan Nusantara (PPN) terhadap Kebutuhan Operasi Penangkapan Ikan. Jurnal Kebijakan Sosial Ekonomi Kelautan dan Perikanan. 2(1): 41-49.

Direktur Jenderal Perikanan Tangkap. 2015. Keputusan Direktur Jenderal Perikanan Tangkap Nomor 20/KEP-DJPT/ 2015 Tentang Pedoman Evaluasi Kinerja Operasional Pelabuhan Perikanan.

Fadhil M. 2016. Pengaruh Kompetensi Sumber Daya Manusia Terhadap Kinerja Pegawai Pada Balai Latihan Kerja Industri Makasar. Jurnal Perspektif. 1(1): 70-81.

Ferdinand, A. 2006. Structural Squation Modeling Dalam Penelitian Manajemen. Semarang: Badan Penerbit Universitas Diponegoro.

Ferdinand, A. 2014. Metode Penelitian Manajemen. Semarang: Badan Universitas Diponegoro.

Ghozali, I. 2014. Structural Equation Modelling, Metode Alternatif dengan Partial Least Square (PLS). Edisi 4. Semarang: Badan Penerbit Universitas Diponegoro.

Gonçalves W, Assumpção MRP. 2016. Structural Equation Modeling for Multivariate Statistical Analysis of the Relationship Between Ports and Regional Economy. Rev. Téc. Ing. Univ. Zulia. 39(7): 126-133.

Gumilang AP, Susilawati E. 2019. Supplay Chain Analysis in the Distribution of Leading Commodity-Based Catches in PPN Kejawanan. Jurnal IImu dan
Teknologi Kelautan Tropis. 11(3): 807814.

Jashari A, Kutllovci E. 2020. The Impact of Human Resource Management Practices on Organizational Performance Case Study: Manufacturing Enterprises in Kosovo. Verslas: Teorija ir praktika / Business: Theory and Practice. 21(1): 222-229.

Juhaeriyah, Sulistiyono ST, Alamsyah. 2018. Perkembangan Pelabuhan Perikanan Nusantara Kejawanan dan Kontribusinya terhadap Pemberdayaan Sosial Ekonomi Masyarakat Nelayan Kota Cirebon, 1994-2011. Indonesian Historical Studies. 2(2): 118-135.

Kementerian Kelautan dan Perikanan. 2018. Keputusan Menteri Kelautan dan Perikanan Republik Indonesia Nomor 6/KEPMEN-KP/2018 tentang Rencana Induk Pelabuhan Perikanan Nasional. $49 \mathrm{hlm}$.

Lubis A, Torong ZB, Muda I. (2016). The Urgency of Implementing Balanced Scorecard System on Local Government in North Sumatra - Indonesia. International Journal of Applied Business \& Economic Research, 14(11): 7575-7590.

Lubis E, Pane AB. 2012. An Optimum Model of Fish Auction in Indonesian Fishing Ports in Accordance with the Characteristics of Fisherman. Journal of Coastas Development. 15(3): 282-296.

Lubis E, Pane AB. 2017. Institusional Model of Fish Auction Refunctionalization in Indonesia Fishing Ports. AACL Bioflux. 10(6): $1456-1465$.

Murdiyanto B. 2004. Pelabuhan Perikanan (Fungsi, Fasilitas, Panduan Operasional, Antrian Kapal). Jurusan Pemanfaatan Sumberdaya Perikanan. Institut Pertanian Bogor. $132 \mathrm{hlm}$.

Munim ZH, Schramm HJ. 2018. The Impacts of Port Infrastructure and Logistics Performance on Economic Growth: The Mediating Role of Seaborne Trade. Journal of Shipping and Trade (JST). 3(1):1-19.

Muninggar R. 2008. Analisis Supply Chain dalam Aktivitas Distribusi di Pelabuhan Perikanan Nusantara Palabuhanratu. Buletin PSP. 12(3): 350 - 355. 
Ngamel YA, Lubis E, Pane AB, Solikhin I. 2013. Kinerja Operasional Pelabuhan Perikanan Nusantara Tual. Jurnal Teknologi Perikanan dan Kelautan. 4(2): 155-172.

Nugraha TS, Khan AMA, Pratama RI, Apriliani IM. 2019. Analisis Keterkaitan Parameter Oseanografi Terhadap Upaya Penangkapan Ikan Tenggiri (Scomberomorus comerson) yang Didaratkan di PPN Kejawanan Cirebon. Jurnal Perikanan dan Kelautan. 10(2): 17-21.

Obi JN. 2015. Effective Human Resources Management Practices as the Key to Organizational Performance. International Journal of Educational Research, Innovations and Methods. 3(1): 1-26.

Okoye PVC, Ezejiofor RA. 2013. The Effect of Human Resources Development on Organizational Productivity. International Journal of Academic Research in Business and Social Sciences. 3(10): 250-268.

Ozkeser B. 2019. Impact of Training on Employee Motivation in Human Resources Management. Procedia Computer Science. 158(2019): 802810.

Presiden Republik Indonesia. 2014. Peraturan Presiden Nomor 191 Tahun 2014 tentang Penyediaan, Pendistribusian dan Harga Jual Eceran Bahan Bakar Minyak. LN.2014/NO.399, LL SetKab: 16 hlm.

Pelabuhan Perikanan Nusantara Kejawanan. 2019. Laporan Tahunan PPN Kejawanan Tahun 2019. $97 \mathrm{hlm}$.

Purnomo $\mathrm{AH}$, Suryawati $\mathrm{SH}$, Hikmayani $\mathrm{Y}$, Reswati E. 2003. Model Pengembangan Industri Perikanan Terpadu (studi kasus di wilayah pengembangan utama iii, Jawa Tengah). Jurnal Penelitian Perikanan Indonesia. 9(6): 35-56.

Ramadhani AR, Ismail, Boesono H. 2015. Analisis Tingkat Pemanfaatan Fasilitas dan Strategi Pengembangan Pelabuhan di Pelabuhan Perikanan Nusantara (PPN) Kejawanan, Cirebon, Jawa Barat. Journal of Fisheries Resources Utilization Management and Technology (JFRUMT). 4(2): 58-68.
Roring RO, Djakfar L, Wicaksono A. 2020. The Effect of Special Economic Zone and International Hub Port Development on the Transportation Infrastructure Provision. International Journal of Innovative Technology and Exploring Engineering (IJITEE). 9(4): 2588-2596.

Ruswandi A, Gartika D. 2013. Strategi Pengembangan Investasi di Sekitar Pelabuhan Perikanan Tipe B di Jawa Barat. Jurnal Akuatika. 4(1): 89-101.

Sharapiyeva MD, Antoni A, Yessenzhigitova R. 2019. The Impact of Port TransportLogistics Infrastructure and LPI for Economic Growth: on the Example of Landlocked Countries. Scientific Journal of Maritime Research 33: 6375.

Shen J, Zhu CJ. 2011. Effects of Socially Responsible Human Resource Management on Employee Organizational Commitment. The International Journal of Human Resource Management. 22(15): 3020-3035.

Sudirman N, Semeidi H, Ruswahyuni. 2013. Baku Mutu Air Laut untuk Kawasan Pelabuhan dan Indeks Pencemaran Perairan di Pelabuhan Perikanan Nusantara Kejawanan, Cirebon. Jurnal Saintek Perikanan. 9(1): 14-22.

Suherman, A. 2007. Rekayasa Model Pengembangan Pelabuhan Perikanan Samudera Cilacap. [Disertasi]. Bogor: Program Pascasarjana, Institut Pertanian Bogor. 307 hlm.

Suherman A, Dault A. 2009. Dampak Sosial Ekonomi Pembangunan Dan Pengembangan Pelabuhan Perikanan Nusantara (PPN) Pengambengan Jembrana Bali. Jurnal Saintek Perikanan. 4(2): 24 $-32$.

Suherman A. 2010. Alternatif Strategi Pengembangan Pelabuhan Perikanan Nusantara Brondong Lamongan Jawa Timur. Jurnal Saintek Perikanan. 5(2): 88-98.

Suherman A. 2011. Formulasi Strategi Pengembangan Pelabuhan Perikanan Pengambengan Jembrana. Jurnal Marine Fisheries. 2(1): 87-99.

Supriadi D, Fitri M. 2019. Analisis Tingkat Kepuasan Nelayan Terhadap Pelayanan Kesyahbandaran di PPN 
Kejawanan Cirebon. Jurnal Barakuda 45. 1(1): 18-26.

Supriadi D, Rahayu S, Gumilang AP. 2020. Komposisi Hasil Tangkapan dan Tingkat Keramahan Jala Cumi (Cast net) di PPN Kejawanan Cirebon Jawa Barat. Jurnal Barakuda 45. 2(1): 1-9.

Villajos E, Tordera N, Peiro JM. 2019. Human Resource Practices, Eudaimonic WellBeing, and Creative Performance: The Mediating Role of Idiosyncratic Deals for Sustainable Human Resource Management. Sustainability Journal. 11(24): 1-20.
Widagdo R. 2015. Peran PPN Kejawanan Dalam Pemberdayaan Ekonomi Masyarakat Pesisir Kota Cirebon. Jurnal Penelitian Hukum dan Ekonomi Syariah. 3(1): 44-62.

Wright PM, Coff R, Moliterno TP. 2013. Strategic Human Capital: Crossing the Great Divide. Journal of Management. 40(2): 353-370.

Yanti BPI, Yulisti M. 2011. Kebijakan Penghapusan Retribusi Perikanan (Analisis Penerapan kebijakan di Kabupaten Pandeglang, Provinsi Banten) Buletin Sosek Kelautan dan Perikanan. 6(1): $14-17$. 